\title{
Modulation of actA gene expression in Listeria monocytogenes by iron
}

\author{
MARIA PIA CONTE, C. LONGHI, G. PETRONE, M. POLIDORO, P. VALENTI* and L. SEGANTI \\ Institute of Microbiology, University of Rome 'La Sapienza', Rome and *Institute of Microbiology, II University \\ of Naples, Naples, Italy
}

\begin{abstract}
This study analysed the invasiveness of Listeria monocytogenes into enterocyte-like Caco2 cells in which iron depletion was achieved by picolinic acid treatment. Both entry and intracellular multiplication varied depending on the endogenous iron content of bacterial and eukaryotic cells. The behaviour within enterocytes was correlated with a 10-fold increased transcription of the act $A$ gene observed in bacterial cells grown under conditions of iron stress.
\end{abstract}

\section{Introduction}

Listeria monocytogenes, a gram-positive bacillus responsible for food-borne infections in animals and man [1], is a facultative intracellular parasite capable of entry, multiplication and movement within target cells [2]. Most of the genes involved in L. monocytogenes virulence are clustered on the chromosome [3] and controlled by the transcriptional activator PrfA $[4,5]$. Expression is controlled by environmental factors [6]; physicochemical signals, including ferric ions, influence virulence gene expression [7-11].

Iron deficiency significantly increases listeriolysin $\mathrm{O}$ production [8-10] and is associated with reduced invasiveness of $L$. monocytogenes cells and with decreased expression of the $\operatorname{inl} A B$ virulence genes which are required for bacterial entry into host cells [10]. Recent data have shown that transcription of the prfA gene is also increased in iron-starved bacteria [12].

However, modulation of the expression of L. monocytogenes virulence genes in an intracellular environment has been less extensively studied. It has been suggested that an enhanced transcription of $p l c A$, encoding for a phosphatidyl inositol-specific phospholipase $\mathrm{C}$, and several other genes occurs during growth within macrophages [13] and that certain cytosolic signals may stimulate the synthesis of ActA [14, 15], a surface-associated protein of 639 amino acids, which is an essential determinant of L. monocytogenes pathogenicity. During intracellular growth, surface-bound ActA supports the formation of tail-like F-actin

Received 8 June 1999; revised version accepted 4 Dec. 1999.

Corresponding author: Dr M. P. Conte. structures, allowing the movement of bacteria into the host cytosol and their spread from cell to cell [16-18].

The objective of the present study was to evaluate the influence of iron availability on actA gene expression by analysing the invasiveness of $L$. monocytogenes and the transcription of the act $A$ gene under different conditions of iron availability.

\section{Materials and methods}

\section{Bacterial strain}

The clinical isolate of L. monocytogenes LM1 used in this study was a haemolytic, wild-type strain capable of invading and multiplying in Caco-2 and HeLa cells, similar to L. monocytogenes ATCC 7644 [19]. Iron limitation $\left(\mathrm{Fe}^{3+}<1 \mu \mathrm{M}\right)$ was achieved by culturing bacteria in low iron medium (LIM) Brain Heart Infusion (BHI; Merck) plus Chelex-100 [10] and with $100 \mu \mathrm{M}$ ethylenediamine-di-o-hydroxyphenylacetic acid (EDDHA). Iron excess conditions were obtained by culturing bacteria in LIM supplemented with $100 \mu \mathrm{M}$ ferric citrate. Previous reports have shown that the growth rate of $L$. monocytogenes in $\mathrm{BHI}$ correlates with the level of assimilable iron $[10,20]$. After $18 \mathrm{~h}$, maximal growth rates of $L$. monocytogenes $\left(\mathrm{OD}_{600} 1.6\right)$ were achieved in iron-rich medium (LIM plus $100 \mu \mathrm{M}$ ferric citrate) as compared with growth rates in LIM $\left(\mathrm{OD}_{600}\right.$ 0.9) [10].

\section{Invasion assays}

Caco-2 cells were grown in 24-well plates for $48 \mathrm{~h}$ in Eagle's minimum essential medium (MEM). Then the medium was replaced by MEM containing $2 \mathrm{mM}$ picolinic acid and fetal calf serum treated with 
Chelex-100 $10 \%$ to remove intracellular iron. After incubation for a further $48 \mathrm{~h}$, iron content was lowered from $125 \mathrm{pM}$ to $18 \mathrm{pM} / 10^{6}$ Caco- 2 cells, as determined by measurement in cytosolic fractions with an atomic adsorption spectrophotometer with a minor modification of the procedure described by Mikogami et al. [21]. Invasion assays of iron-depleted or iron-loaded Caco-2 cells were performed as described previously [19], at an infective dose of c. 100 log-phase bacteria/cell. After incubation for $1 \mathrm{~h}$ at $37^{\circ} \mathrm{C}$, infected monolayers were washed five times in MEM, and $1 \mathrm{ml}$ of fresh medium containing gentamicin $5 \mu \mathrm{g} / \mathrm{ml}$ was added to each well. After incubation for a further $1 \mathrm{~h}$ at $37^{\circ} \mathrm{C}$, the cells were lysed by the addition of cold Triton X-100 $0.1 \%$ and plated to determine the number of viable intracellular bacteria. The intracellular replication of $L$. monocytogenes in iron-depleted or iron-loaded Caco- 2 cells was determined according to the method of Conte et al. [19].

\section{Transcriptional analysis of actA gene}

Total cellular RNA was extracted $[10,22]$ from logphase cells of L. monocytogenes in LIM and LIM supplemented with ferric ions. Samples of $5 \mu \mathrm{g}$ of total RNA were mixed with three volumes of denaturing solution (0.4 M 3-(N-morpholino)-propanesulphonic acid, $10 \mathrm{mM}$ sodium acetate, $1 \mathrm{mM}$ EDTA; formamide $50 \% ; 2.2 \mathrm{M}$ formaldehyde), incubated at $65^{\circ} \mathrm{C}$ for $5 \mathrm{~min}$, and placed on ice. After addition of $600 \mu \mathrm{l}$ of $10 \times \mathrm{SSC}(1 \times \mathrm{SSC}$ is $0.15 \mathrm{M} \mathrm{NaCl}$ plus $0.015 \mathrm{M}$ sodium citrate) samples were vacuum-blotted with a BioRad slot-blot apparatus on to Hybond ${ }^{\mathrm{TM}}-\mathrm{C}$ extra nitrocellulose membranes (Amersham) previously soaked in the same solution. RNA was cross-linked to the membrane by baking at $80^{\circ} \mathrm{C}$ for $2 \mathrm{~h}$. The total amount of RNA present in each slot was checked by probing the membranes with a $16 \mathrm{~S}$ rDNA probe from L. monocytogenes LM1. Membrane hybridisation and washings were performed as described previously [10]. Transcription of actA was monitored by an intragenic probe made by PCR in which two oligonucleotides annealing to bp 907-925 of the non-coding strand and to bp 1285-1306 of the coding strand of the published sequence were used as primers [23]. Hybridisation was monitored by a blot analyser (Betascope model 603, Betagen, MA, USA).

\section{Results and discussion}

The invasion of Caco- 2 cells by L. monocytogenes varied depending on the endogenous iron in both bacteria and cells (Fig. 1a and b). At $3 \mathrm{~h}$ after the addition of bacteria to untreated Caco-2, the number of viable intracellular bacteria grown in iron-limited medium was significantly less than for bacteria grown in iron excess conditions $(\mathrm{p}<0.05)$ (Fig. 1a). Iron availability in Caco-2 cells also affected bacterial invasion during the first $3 \mathrm{~h}$ of incubation; viable intracellular bacterial cells decreased from 5.25 to $4.6 \log _{10} \mathrm{cfu} / \mathrm{ml}$ for iron-limited bacteria and from 4.6 to $4.3 \log _{10} \mathrm{cfu} / \mathrm{ml}$ for iron-rich bacteria (Fig. 1a and b). Further incubation in iron-loaded Caco-2 cells resulted in a rapid increase in the number of intracellular iron-limited bacteria to numbers similar to those seen with iron-rich bacteria (Fig. 1a). Similarly, further incubation in iron-depleted Caco- 2 cells resulted in increased numbers of intracellular bacteria whether grown under iron-limited or iron-rich conditions (Fig. 1b). After incubation for $7 \mathrm{~h}$, the numbers of intracellular bacteria were very similar whatever the iron availability conditions.

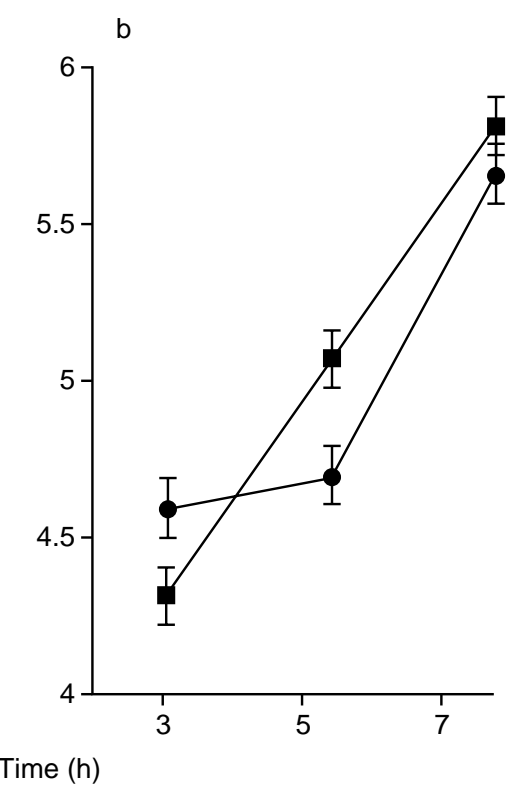

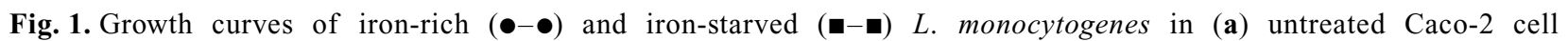
monolayers and (b) picolinic acid-treated cell monolayers. Results are presented as the mean (SD) $\log _{10} \mathrm{cfu}$ of four independent experiments. 
Microscopy of intracellular bacteria stained with tetramethyl rhodamine isothiocyanate-conjugated phalloidin showed that the ability to form tail-like structures (dependent upon the polymerisation of host actin by ActA) was more efficient when bacteria and host cells were iron-depleted (data not shown).

To investigate whether iron affects the invasive phenotype of L. monocytogenes LM1 by regulating the expression of the actA gene at the transcriptional level, slot-blot analyses were performed with total cell RNA extracted from L. monocytogenes cells grown in LIM or LIM supplemented with ferric ions. Hybridisation with the actA probe of RNA extracted from irondeficient bacteria resulted in a 10.6-fold increase in hybridisation signal as compared with RNA from ironrich bacteria (Fig. 2). However, a growth condition of iron excess was not sufficient to repress totally the transcription of the actAgene.

The role of iron as a regulator of virulence gene expression in L. monocytogenes is well established $[8,10,12]$. Within host cells, two genes, hly and actA, which encode for listeriolysin and ActA, respectively, are expressed preferentially during bacterial intracellular growth and are required to establish intracellular infection [15]. The present study has provided further insight into the role of iron as a regulator of virulence gene expression. It demonstrated that the transcription of the actA gene in iron-stressed bacteria is 10 -fold higher than in iron-rich bacteria, indicating that the $a c t A$ gene is up-regulated under iron-stress conditions, similarly to the $h l y$ and $\operatorname{prfA}$ genes located in the same virulence cluster $[10,12]$. Consequently, in iron-depleted cell monolayers the increased bacterial growth rate observed may be related not only to enhanced listeriolysin $\mathrm{O}$ synthesis which occurs in iron-stressed bacteria $[8,10]$, but also to increased actA expression, although other effects of iron depletion on mammalian cell physiology cannot be ruled out.

This work was supported by Cofin 9806260379-004 and MURST grants.

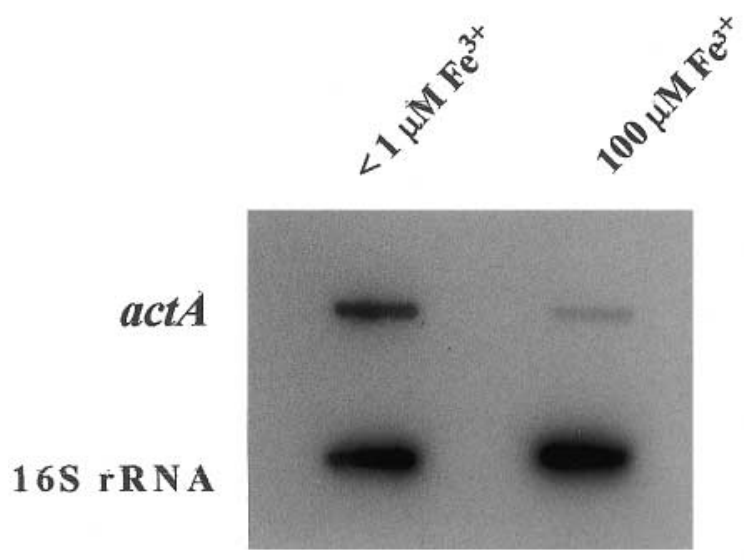

Fig. 2. Transcriptional analysis of the actA gene of $L$. monocytogenes LM1 grown under iron-poor $\left(\mathrm{Fe}^{3+}<1 \mu \mathrm{M}\right)$ and iron-rich conditions $\left(100 \mu \mathrm{M} \mathrm{Fe}^{3+}\right)$.

\section{References}

1. Farber JM, Peterkin PI. Listeria monocytogenes, a food-borne pathogen. Microbiol Rev 1991; 55: 476-511.

2. Portnoy DA. Cellular biology of Listeria monocytogenes infection. In: Miller VL, Kuper JB, Portnoy DA, Isberg RR (eds) Molecular genetics of bacterial pathogenesis. Washington, DC, American Society for Microbiology. 1994: 279-293.

3. Portnoy DA, Chakraborty T, Goebel W, Cossart P. Molecular determinants of Listeria monocytogenes pathogenesis. Infect Immun 1992; 60: 1263-1267.

4. Leimeister-Wächter M, Haffner C, Domann E, Goebel W, Chakraborty $\mathrm{T}$. Identification of a gene that positively regulates expression of listeriolysin, the major virulence factor of Listeria monocytogenes. Proc Natl Acad Sci USA 1990; 87: 8336-8340.

5. Mengaud J, Dramsi S, Gouin E, Vasquez-Boland JA, Milon G, Cossart P. Pleiotropic control of Listeria monocytogenes virulence factors by a gene that is autoregulated. Mol Microbiol 1991; 5: 2273-2283.

6. Brehm K, Kreft J, Ripio MT, Vazquez-Boland JA. Regulation of virulence gene expression in pathogenic Listeria. Microbiologica 1996; 12: 219-236.

7. Geoffroy C, Gaillard J-L, Alouf JE, Berche P. Purification characterization, and toxicity of the sulphidryl-activated hemolysin listeriolysin $\mathrm{O}$ from Listeria monocytogenes. Infect Immun 1987; 55: 1641-1646.

8. Cowart RE, Foster BG. The role of iron in the production of haemolysin by Listeria monocytogenes. Curr Microbiol 1981; 6: $287-290$.

9. Deneer HG, Healey V, Boychuk I. Reduction of exogenous ferric iron by a surface-associated ferric reductase of Listeria spp. Microbiology 1995; 141: 1985-1992.

10. Conte MP, Longhi C, Polidoro M et al. Iron availability affects entry of Listeria monocytogenes into the enterocyte-like cell line Caco-2. Infect Immun 1996; 64: 3925-3929.

11. Litwin CM, Calderwood SB. Role of iron in regulation of virulence genes. Clin Microbiol Rev 1993; 6: 137-149.

12. Böckmann R, Dickneite C, Middendorf B, Goebel W, Sokolovic Z. Specific binding of the Listeria monocytogenes transcriptional regulator PrfA to target sequences requires additional factor(s) and is influenced by iron. Mol Microbiol 1996; 22: 643-653.

13. Klarsfeld AD, Goossens PL, Cossart P. Five Listeria monocytogenes genes preferentially expressed in infected mammalian cells: plcA, purH, purD, purE, and an arginine ABC transporter gene, arpJ. Mol Microbiol 1994; 13: 585-597.

14. Bohne J, Sokolovic Z, Goebel W. Transcriptional regulation of prfA and PrfA-regulated virulence genes in Listeria monocytogenes. Mol Microbiol 1994; 11: 1141-1150.

15. Moors MA, Levitt B, Youngman P, Portnoy DA. Expression of listeriolysin $\mathrm{O}$ and ActA by intracellular and extracellular Listeria monocytogenes. Infect Immun 1999; 67: 131-139.

16. Cossart P. Actin-based bacterial motility. Curr Opin Cell Biol 1995; 7: 94-101.

17. Smith GA, Portnoy DA. How the Listeria monocytogenes ActA protein converts actin polymerization into a motile force. Trends Microbiol 1997; 5: 272-276.

18. Tilney LG, Portnoy DA. Actin filaments and the growth, movement, and spread of the intracellular bacterial parasite Listeria monocytogenes. J Cell Biol 1989; 109: 1597-1608.

19. Conte MP, Longhi C, Petrone G, Polidoro M, Valenti P, Seganti L. Listeria monocytogenes infection of Caco-2 cells: role of growth temperature. Res Microbiol 1994; 145: 677-682.

20. Cowart RE, Foster BG. Differential effects of iron on the growth of Listeria monocytogenes: minimum requirements and mechanism of acquisition. J Infect Dis 1985; 151: 721-730.

21. Mikogami T, Marianne T, Spik G. Effect of intracellular iron depletion by picolinic acid on expression of the lactoferrin receptor in the human colon carcinoma cell subclone HT-29-

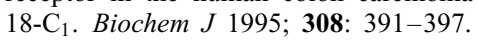

22. Sambrook J, Fritsch EF, Maniatis T. Molecular cloning: a laboratory manual, 2nd edn. Cold Spring Harbor, NY, Cold Spring Harbor Laboratory Press. 1989.

23. Vazquez-Boland J-A, Kocks C, Dramsi S et al. Nucleotide sequence of the lecithinase operon of Listeria monocytogenes and possible role of lecithinase in cell-to-cell spread. Infect Immun 1992; 60: 219-230. 